\title{
Ethnoecological knowledge of the artisan fishermen of octopi (Octopus spp.) in the community of Coroa Vermelha (Santa Cruz Cabrália, Bahia)
}

\author{
VIVIANE S. MARTINS ${ }^{1}$, ALEXANDRE SCHIAVETTI ${ }^{2}$ and FRANCISCO J.B. SOUTO ${ }^{3}$ \\ ${ }^{1}$ Universidade Estadual de Campinas/UNICAMP, Núcleo de Estudos e Pesquisas Ambientais/(NEPAM) \\ Rua dos Flamboyants, 155, Cidade Universitária Zeferino Vaz, 13083-867 Campinas, São Paulo, Brasil \\ ${ }^{2}$ Universidade Estadual de Santa Cruz/UESC, Campus Soane Nazaré de Andrade, Km 16 \\ Rodovia Ilhéus-Itabuna, 45650-000 Ilhéus, BA, Brasil \\ ${ }^{3}$ Universidade Estadual de Feira de Santana/UEFS, Km 03, BR 116 \\ Campus Universitário, 44031-460 Feira de Santana, BA, Brasil
}

Manuscript received on September 2, 2009; accepted for publication on August 5, 2010

\begin{abstract}
Coral reefs are quite diverse ecosystems that carry out several ecological functions and plays a relevant socioeconomic role. The artisan fishing of octopi (Octopus spp.) is practiced for the survival of part of the inhabitants of Coroa Vermelha community, in the south of the state of Bahia. We intended to study the knowledge of the octopi fishermen of Coroa Vermelha using the comprehensive ethnoecological proposal of Marques. The data were collected between July, 2006 and April, 2008 through direct observation and from interviews with fishermen met by chance and through the "native specialists" criterion. Twenty semi-structured interviews were carried out following an itinerary of pre-established questions about the activity of octopi capture, and the biological and ecological aspects of the resource. The data showed that the fishermen have knowledge about biological and ecological aspects of the octopi. Two capture techniques are used: octopus fishing (polvejamento) in the reefs and through diving. Two specific folk are recognized: the "normal octopus" (Octopus insularis) and the "east octopus" (Octopus macropus (?)). The intervieews demonstrated ecological knowledge sometimes compatible with the scientific literature, mainly in which concerns the trophic ecology and behavior of the octopi.
\end{abstract}

Key words: ethnoecology, artisan fishing, coral reefs, cephalopod.

\section{INTRODUCTION}

The corals reefs are marine ecosystems found in hot and clear waters and they are among the most productive ecossystems in the world. Besides being an ecosystem with great wealth of species, acting as a stabilizer of the coast line and serving as a shelter for juveniles of several animal groups, this environment also plays an important socioeconomic role, both due to the supply of fishing resources that sustain several communities, and the tourist potential that it represents.

These resources have a historical importance in the subsistence of several traditional coastal communities

Correspondence to: Viviane Souza Martins

E-mail: martins.viviane@gmail.com
(Johannes 1981, Diegues 2001, Vergara-Filho 2001). According to Diegues (2000), these populations build a singular way of life over time, acquiring their own way of dealing with these resources and incorporating their knowledge to their habits and religious practices.

The Coroa Vermelha district, located in the municipality of Santa Cruz Cabrália, in the southern most part of the state of Bahia, is an example of community where the fishing activities are still essential for the survival of great part of the inhabitants. Although tourism is an alternative increasingly promising in the community, subsistence is strongly associated to fishing. The catch of octopus is one of the most important fishing activities in the Coroa Vermelha district. Other target species caught are shrimp, fish and lobsters. 
According to the comprehensive ethnoecological proposal of Marques (2001), the ethnoecology is "the field of transdisciplinar (scientific) research that studies the thoughts (knowledge and beliefs), feelings and behaviors that intermediate the interactions between human populations and other elements of the ecosystem that include them, as well as the environmental impacts derived from them".

Being part of the comprehensive ethnoecological proposal (Marques 1995) knowledge is treated in cognitive bases, the feelings in pathos and behaviors in connective bases. A key aspect in the comprehensive ethnoecology is the five basic connections that human beings have with the environment: human being/mineral, human being/vegetable, human being/animal, human being/human being and human being/supernatural.

Artisan fishing has been raising the interest of a growing number of ethnoecology researchers. Since the beginning of the 1990's, several works have been developed in Brazil, especially the studies of Marques (1991) in the estuarine-lagoon complex Mundau-Manguaba in Alagoas, Nishida (2000) along the Paraíba coast, Mourão (2000) in the Mamanguape River, Paraíba, Costa Neto (2001) in the north coast of Bahia, Montenegro (2002) in the low São Francisco River in Alagoas, Souto (2004) in the Recôncavo Baiano, and Mourão and Nordi (2006) in estuary communities of Paraíba, among others.

One of the themes within the ethnobiology studies in Brazil is ethnotaxonomy, which, according to Posey (1987), investigates the universality of human capacity to classify. Berlin (1992) created principles of the folk classification looking for patterns in the living beings' classification accomplished by illiterate societies. This was a great achievement in the ethnotaxonomy studies. Research regarding artisan or craft fishing with an ethnoecological approach, accomplished in Brazil, (e.g. Marques 1991, Mourão 2000, Souto 2004, Mourão and Montenegro 2006) have been reflecting the specialists' great interest in understanding the popular taxonomy, mainly in which it refers to fish classification.

In Bahia State, at the northeast area of the Brazilian coast, artisan fishing corresponds to almost all the fishing catches (Souto 2004). According to SEAP (2004), the professional fisherman of artisan fishing is "the one who, with his/her own means of production, performs his/her activity in an independent way, individually or within a family economy system or, also, with the possible aid of other partners, without an employment bond". The artisan fishing is also characterized by involving instruments of little technology and obtaining resources in a small scale when compared to the industrial fishing.

The octopi are important fishing resources in several countries worldwide and in Brazil they are captured almost exclusively in an artisan way. The area of Mediterranean stands out in terms of fishing commercial landing (Quetglas et al. 1998, Tsangridis et al. 2002). Commercial fleets of relevance for the fishing sector also act in other parts of the world, where, in most cases, the octopi are captured as accompanying fauna in the shrimp fishing (Santamariña 1998).

In Brazil, some studies on the industrial fishing of octopi have been developed (e.g. Tomás 2003). However, the artisan fishing of octopi have only begun to be studied very recently in Brazil by Leite (2007) in the Archipelago of Fernando de Noronha which is the only reference found in this regard. No research on any kind of approach concerning the ethnoecological aspects of octopus fishing was carried out in the country until the present.

Due to the lack of studies on the artisan fishing of the octopus in Brazil, as well as the wealth of the culture and the biodiversity of the studied area, the objective of this work was to evaluate the ethnoecological knowledge of the octopus fishermen of Coroa Vermelha on the biological and ecological aspects of octopus and other elements of its ecosystem.

\section{METHODOLOGY}

The district of Coroa Vermelha, municipality of Santa Cruz Cabrália, is located in the southernmost part of the state of Bahia (Fig. 1). On June 7, 1993, due to the presence of sandbank environments, remaining Atlantic forest, mangroves and corals reefs, it was created, through State Decree number 2,184, the Area of Environmental Protection of Coroa Vermelha (Área de Proteção Ambiental - APA, in portuguese), comprising 4,100 ha of extension (SEMARH 2007), a protected area (PA) by IUCN classified as Class V. In this APA 


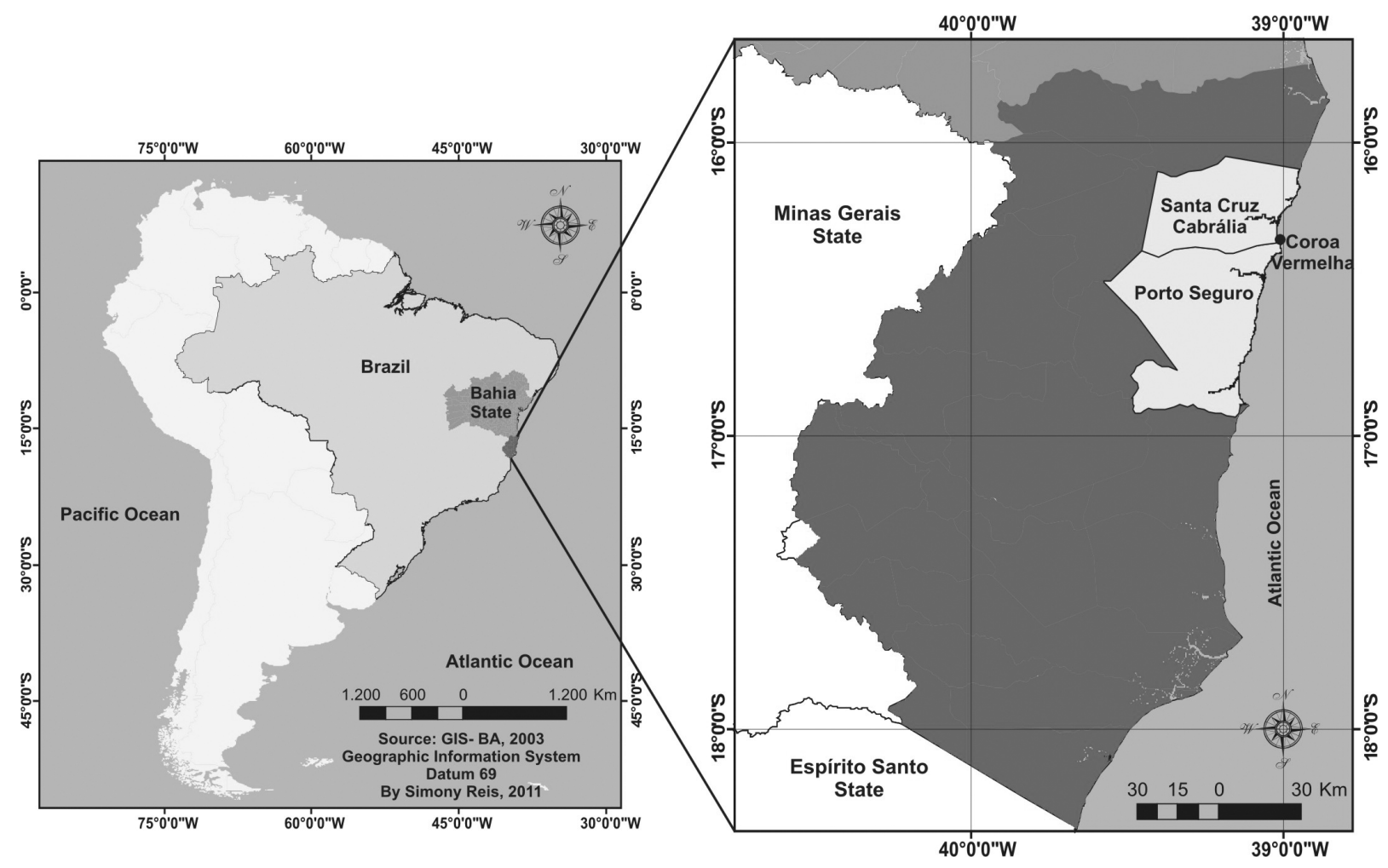

Fig. 1 - Location of Coroa Vermelha district.

there is the indigenous village of Coroa Vermelha, inserted in Indigenous Land (IL) officially recognized by the Brazilian government, where about 850 families of the ethnic group Pataxó live in an area of 1,494 ha.

The field activities began in July 2006 and were concluded in April, 2008. It was made 7 field trips, each one with an average duration of one week. Initially, non-structured interviews (Richardson et al. 2007) were done aiming to apprehend the native speech, to understand the community's dynamic and to establish the rapport. After this, 20 semi-structured interviews were carried out following an itinerary of pre-established questions about the activity of octopi capture, and the biological and ecological aspects of the resource. The interviews were recorded using a digital tape recorder and then transcribed.

The interviewees were contacted at random from indications of another fisherman or following the "native specialists" criterion (Marques 1995). At the end of each semi-structured interview, each informer was requested to indicated other octopus fishermen, following the "snowball" technique (Bailey apud Silvano
2001). The number of interviewees was considered satisfactory from the moment the indicated fishermen had already been interviewed and it was impossible to add new interviewees to the sample. According to the orientation of the Committee of Ethics in Research of Santa Cruz State University (ZIP CODE-UESC), the interviews were always preceded by the reading of the Term of Free and Clarified Consent.

The data emic-etic analysis (approaching the knowledge of the studied community and academic knowledge, respectively) was made through the memes capture - recognizable fragments of cultural information passed from a person to another person (Dawkins 1979, Blackmore 2000) - and for comparison with the scientific literature, generating tables of compared cognition. Together with the interviews, a study of corporal topography (Fig. 2) was done in which, from an illustration, the interviewed fishermen identified with vernacular names the parts of the body of the octopus that could be useful for the ethnotaxonomy of the animal.

Visually interviews were carried out with the purpose of supplying subsidies for the identification of the 


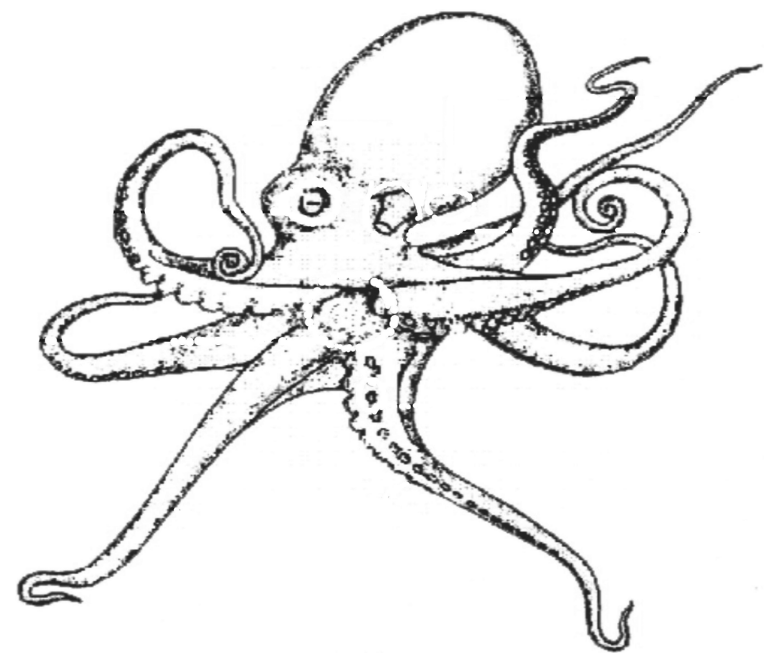

Fig. 2 - Picture used in the corporal topography study during the interviews (adapted from Brusca and Brusca 2007).

"east octopus" that, given its rarity, it was not obtained for identification. For this, a sequence of six images of different species was shown to the interviewees in order to have the "east octopus" identificated. The pictures showed to the interviewees referred to Octopus defilippi, O. burryi, O. joubini, O. maya, O. macropus and O. vulgaris and were obtained in a specific site of researches on cephalopods (www.cephbase.utmb.edu 2007).

During the whole study the technique of direct observation was also used, in which the fishermen were accompanied and photographed in his/her fishing activity.

Specimens of octopus were collected for taxonomic identification performed by an academic specialist. The specimens of identified octopi are deposited in the Laboratory of Demersal Fish and Cephalopods Resources of the Oceanography Department of the Federal University of Rio Grande do Sul (RS). The recorded and transcribed material is in the Laboratory of Ethnobiology and Ethnoecology of the State University of Feira de Santana, Brazil.

\section{RESULTS AND DISCUSSION}

\section{Characterization of the Fishing ACtivity}

The "octopus fishing" in Coroa Vermelha is also denominated "polvejamento" and its executors are known locally as octopus fishermen, but they can also be called "polvejadores". There is no prohibition, restriction or any legal impediment for the practice of the activity in any period of the year.

That activity is performed predominantly by men in the community $(90 \%, \mathrm{n}=18)$, although some few women fish for octopus $(10 \%, \mathrm{n}=2)$. The octopus fishermen also perform other activities that complement the family income. Among the interviewees, 85\% carried out another fishing activity in other words, they do not fish octopus exclusively.

The octopus fishing can be carried out both for economical purposes (for commercialization) and for consumption. Among the interviewees $(n=20), 70 \%$ captured octopi for sale and eventual consumption, and the remaining ones aim at the consumption and, eventually, commercialize the product.

Most of the interviewees fish with line and fishhook and/or fishing net. The shrimp fishing, when carried out by octopus fishermen is, generally, the main source of income of the family, in this case, the octopus fishing is less frequent. Besides fishing activities, the octopus fishermen have other alternatives of income, mainly those focused direct or indirectly on tourism (" [...] When the octopus is difficult for us, we catch fish: when it is not fish it is shrimp, and so on. We don't do only one thing here").

Fishing for octopus does not need, necessarily, a fishing boat to be performed and, for this reason, this activity can be considered accessible from the logistics point of view.

\section{HYDRODYNAMICS}

The dynamics of the tides is a decisive factor for the execution of one of the strategies for the octopus capture: the octopus fishing from the reefs. The octopus fishermen search the resource during the low tide and the activity is interrupted as soon as the rocks begin to be flooded again. The ideal period for this kind of octopus fishing is during the syzygy tides. The capture of octopi by diving can be carried out at any period and, therefore, does not depend on the tides.

Due to the strong relationship between fishing and the movement of tides, the fishermen developed knowledge on this abiotic content naming the stages of the cycle. This knowledge is always connected to the transitions of the lunar phases and is especially described 
in full detail by those octopus fishermen that use fishing boat to carry out their works.

According to the interviewees, the tides can be big or dead. The big tides are the lowest, leaving the reefs uncovered ("[...] the big tide dries completely, uncovering everything"). That type of tide includes the syzygy tide in academic terminology. The big tides, "good for octopus" extend over the last two days of the crescent and waning moons until the first two days of the full and new moons. In that period, the width of the tide is going increasing and the reefs fill more during the high tide and they dry more during the low tide.

The period of dead tide includes the low tide and is not favorable to the octopus fishing on the reef plateau. During the end of the period of the big tide, the reefs are still exposed, which theoretically would allow the octopus fishing. However, the amount of octopi in this period decreases a lot due to the fishing effort that was done previously. For this reason, when the tide is going "later" (emptying later), the number of octopus fishermen on the reefs is quite reduced. Moreover, the dead tide does not allow the octopus fishing because, during this phase, the tidal width is small, leaving the reefs always flooded. The interval sequence between the tides, according to the octopus fishermen, refers to the periods in which the tides "are growing" (the transition between the dead tide and the big tide) or "are dying" (period between the big and dead tides). Unfortunately, there aren't statistical fishing data for the catch of octopus in the region due to fishing being blurred.

The "dead tides" occur in the transition periods from new to crescent moons and from full to waning moons while the "big tides" coincide with the transitions from waning to new moons and from crescent to full moons. The "big tides", appropriate period for octopus fishing in the reefs plateau, occur twice a month and are divided by the fishermen into "clear tide" and "dark tide" in reference to the lunar phase in which the periods occur: associated to the arrival of the full and new moons respectively.

\section{ETHNOTAXONOMY}

In Coroa Vermelha for most of the octopus fishermen, the octopus is inserted in a category locally named shellfish. Other animals, such as guaiás (e.g. Calappa gal- lus), siris (Portunidae), shrimps (Crustacea Decapoda), crabs (Ocypodidae), lobsters (Palinuridae), conchas (Bivalvia) and buzos (Gastropoda) are also considered by the interviewees as shellfish, whereas the fishes are excluded from this group.

Applying Berlin (1992) classification principles, the generic octopus is polytypic, including two specific ones: the "common octopus", also called "normal octopus", "traditional octopus" or "real octopus", and the "east octopus". The common octopus samples that were identified belong to the Octopus insularis (Leite \& Haimovici, 2008) species. This species was recently described on the Fernando de Noronha Archipelago (Leite et al. 2008c) and it had not been reported for the Bahia coast. The possibility of occurrence (and consequent exploitation) of Octopus vulgaris in the area of study has not been discharged. From the taxonomic point of view, it is extremely difficult to differentiate the two species from external morphological characters.

It is clearly observed in the local ethnoclassification the existence of a reference model (Marques 1991), the "common octopus", which the second one is classified (" [...] that's the octopus that we really eat, the same normal octopus, now the one of east is the one that is different, and it is called east octopus"). This classification pattern resembles the one found by the author previously mentioned, among fishermen in the Complexo Mundau-Manguaba for the classification of the catfish, that starts from the "real catfish" the other types have their characteristics defined. The "common octopus" is, therefore, the prototypical member (Berlin 1992) because the generic folk in which it is included acts more faithfully and, also, because it is more relevant in cultural and economical terms in the local community's context (Mourão 2000).

Considering the possibility of the simultaneous occurrence of $O$. insularis and $O$. vulgaris in the area, of study there are two possible classifications of the prototypical member named locally ("common octopus"). The first one considers that the specific folk corresponds to a single biological species: $O$. insularis, and the second one is that "common octopus" includes two different species: $O$. insularis and $O$. vulgaris, if the occurrence of the second species in the area of study is confirmed.

The biological classification of octopi is quite com- 
plex including a lot of synonymies and genus revisions (FAO 2002). In the taxonomy of this group many cases of grouping of different species exist in the same specific taxon forming a complex of species. The complex O. vulgaris is a very illustrative example of this situation: this one was considered a cosmopolitan species but as new studies have been carried out and new groups described its distribution has been questioned. Some authors estimate that the occurrence of this species is restricted to Mediterranean and the East portion of the Atlantic Ocean (Belcari et al. 2002). However, DNA studies of distant populations have confirmed the occurrence of the same species also in western Atlantic Ocean and northwest of Pacific (Warnke et al. 2004). The species Octopus insularis was included in the $O$. vulgaris complex (Leite et al. 2008c).

The second type of octopus recognized by the interviewees is known as "east octopus". This denomination is due to an ecological characteristic which emphasis on a space-temporal aspect that is the fact of the (rare) occurrence of this animal to be associated with the east wind. In this case, the folk classification reflects the hierarchical/ecological overlap pattern (Marques 1991) that consists in maintaining a hierarchical cognitive system that fits together with an ecological characteristic.

Due to the rareness of its occurrence no sample of "east octopus" was obtained for taxonomic identification. However, morphological and ethological characteristics mentioned by the octopus fishermen in interviews suggest a taxonomic track for the "east octopus" (Fig. 3). It is probably the Octopus macropus species that occurs in shallow waters in the tropical area of the East and West Atlantic Ocean (Boletzky et al. 2001), and its presence was reported in the Central Atlantic Ocean's waters by the FAO (2002). In Brazil, there is report of this species on the coast of Rio Grande do Norte, Pernambuco, Archipelagos of Fernando de Noronha, São Pedro and São Paulo and Atol das Rocas (Leite 2002 apud Leite and Mather 2008).

Once some morphological and ethological aspects mentioned by the interviewees indicated the correspondence between "east octopus" and O. macropus, visually stimulated interviews with the fishermen were accomplished. Eleven octopus fishermen answered the questions, among which ten pointed to the image of this species as being the "east octopus", which confers larger assurance to the hypothesized taxonomic track.

The direction and intensity of winds, according to Semmens et al. (2007), are among the factors considered important to influence the distribution and migration patterns of several species of cephalopods. The information in literature that associates the occurrence of O. macropus with the direction parameter of winds was not found. However, since this may be an important feature to the distribution of cephalopods such hypothesis should not be excluded.

\section{TROPHIC ECOLOGY}

The interviewed octopus fishermen demonstrated a deep knowledge about the trophic relationships involving the octopus. The food items presented in the diet of this animal are essential for the development of the octopus fishing since the identification of the octopus shelter is possible mainly due to the food leftovers found around its burrow ("[...] you walk there, you see its hole and some crab, shells, other shells, guaia*, and other animals remain from the sea that it eats. Then everything is there, around its house, you see?"). The knowledge about the feeding of the octopi seems to be formed by a useful cultural strategy to optimize the behavior of the octopus dealer as a predator, allowing the latter the possibility of getting the maximum of resources without the minimum necessary effort (energy). The components of the octopus diet most mentioned by the fishermen were the siris (Portunidae), some types of crabs, among them the guaias* (e.g. Calappa gallus), the mollusks (Gastropoda), the conches (Bivalvia), and the lobsters (Pannulirus spp. ${ }^{1}$ ).

The scientific literature (Cardoso et al. 2004, Materazzi 2006, Ruppert et al. 2005) indicates the crustaceans as the favorite preys of the Octopus genus, and the gastropod mollusks are also mentioned by Jambeiro (2002) as alimentary items of Octopus vulgaris, several types of mollusks and fish are also mentioned by Leite et al. (2008b) as part of the diet of $O$. insularis. Thus, this information supported the octopus fishermen knowledge. Fishes are included among preys of

\footnotetext{
${ }^{1}$ Identified according to taxonomic track (based on scientific and colloquial names and their local species occurrence).
} 


\begin{tabular}{|c|c|c|}
\hline Characteristic & Emic quotation for east octopus & Ethic quotation for Octopus macropus \\
\hline $\begin{array}{l}\text { Body color (ruddy, } \\
\text { spotted) }\end{array}$ & $\begin{array}{l}\text { "It is a kind of octopus reddish, it is a lot } \\
\text { different from the other, enterely reddish } \\
\text { and white." }\end{array}$ & $\begin{array}{l}\text { Octopus macropus is known in many } \\
\text { countries as the spotted octopus due to its } \\
\text { white spots along the body (FAO 2002) }\end{array}$ \\
\hline $\begin{array}{l}\text { Long and thin } \\
\text { radial arms or } \\
\text { tentacles }\end{array}$ & $\begin{array}{l}\text { "There is the octopus that we catch here } \\
\text { and there is the east octopus, ok? Its } \\
\text { raios (arms) measures almost one meter } \\
\text { but it is very thin like this finger." }\end{array}$ & $\begin{array}{l}\text { Body measuring } 15 \text { centimeters and arms } \\
\text { with more than one meter length (CEPH- } \\
\text { BASE 2007). }\end{array}$ \\
\hline Nocturnal behavior & $\begin{array}{l}\text { "The east octopus appears only at } \\
\text { night. It is not found during the day, I } \\
\text { have never heard about finding east oc- } \\
\text { topus during the day." }\end{array}$ & $\begin{array}{l}\text { Octopus macropus is an animal mostly } \\
\text { or exclusively nocturnal (Boletzky et al. } \\
2002 \text {, Meisel et al. 2006). }\end{array}$ \\
\hline Rare occurrence & $\begin{array}{l}\text { "[...] We sometimes catch one or two by } \\
\text { chance. But it is difficult. It's so far to } \\
\text { catch one, doesn't it? The hardest thing } \\
\text { is to catch one of these octopus." }\end{array}$ & $\begin{array}{l}\text { Octopus macropus is among the octopi } \\
\text { species that are found in the Archipelago } \\
\text { of Fernando de Noronha. Their noctur- } \\
\text { nal habit makes the fishing impractica- } \\
\text { ble (Leite 2007). }\end{array}$ \\
\hline
\end{tabular}

Fig. 3 - Information that suggests the correspondence between the specific east octopus and the Octopus macropus species according to emic and ethic information respectively.

different species of Octopus (e.g. Forsythe and Hanlon 1997, Quetglas et al. 1998, Jambeiro 2002, Cardoso et al. 2004, Materazzi 2006), and probably due to the lack of food signs around the burrows, most of the interviewees did not refer to fish as alimentary resources for the octopi.

The knowledge of the octopus fishermen about the predation of octopi is also very similar to that found in scientific literature. According to the interviewees, the caramuru or moray eel (Muraenidae), the cação-li$x a$ (Ginglymostoma cirratum), the ray (Dasyatidae) and other fishes are the main predators of octopi. Leite et al. (2008a) assign the predation of octopi in the Archipelago of Fernando de Noronha mainly to the green moray eel (Gymnothorax funebris), to the butter ray (Dasyatis americana) and to the nurse shark (Ginglymostoma cirratum), which corroborate the knowledge of the octopus fishermen. Sea birds and cetaceans are also mentioned in the scientific literature (e.g. Gurjão et al. 2004) as predators of octopi, but the interviewees did not make any reference to these predators. Due to the efficiency attributed to the nurse shark as an octopus predator, good fishermen are locally known as "lixa" (nurse shark): ("[...] people here say that when the guy is very good with octopi, finds a lot, plenty of them, they speak like this: 'Jack is a lixa (nurse shark), isn't he?'. Because the nurse shark eats octopus, the seafood for the nurse shark is the octopus"). In general, in which refers to the trophic ecology and food behavior of octopi, there is a great correspondence among the knowledge of the fishermen (emic) and of the scientific literature (ethic).

\section{SEXUAL Dimorphism}

Most of the fishermen interviewed in Coroa Vermelha affirmed to distinguish the gender of the octopi. The sex differences are related to the size of the animal and to the length and thickness of their arms. According to the description of the fishermen, the male's arms are larger and thinner than those of the females.

Sexual dimorphism is an absent characteristic in most of the octopi of the Octopus genus. However, according to Leite et al. (2008c), the Octopus insularis species has very subtle sexual dimorphism that is shown exactly in the thickness of the animal's arms. Nevertheless, according to the description of the species, the males present thicker arms compared to the females, which is exactly the opposite to the local octopus fishermen speech.

There is also the possibility of what the octopus fishermen notice as dimorphism may correspond to the two different species. The males, which in the intervie- 
wees' perception present the format of a prolonged and lanky body and have thinner arms may correspond to O. vulgaris, while the females that, according to them, present a round body and have arms thicker than the males ones, may belong to the $O$. insularis species.

If the occurrence of $O$. vulgaris in the study area cannot be confirmed, none of the hypotheses can be refused. It can just be established that, in fact, there is among the fishermen a quite solid meme of the differentiation of the genders of the octopi based on morphological characteristics.

\section{ETHOLOGY}

The octopi exhibit camouflage behavior when threatened, in aggressive responses, or during courtship. Octopus fishermen notice, admire this phenomenon and affirm that the octopus "imitates the bottom" for not being found by its predators (including the own octopus fishermen). Octopi, in general, have the capacity of camouflaging at the bottom of where they are. This phenomenon happens because muscular cells contract, making possible the expansion of the chromatophores and, consequently, the change of the surface coloration of their body (Hanlon 2007).

Also with the function of camouflaging to imitate the environment, some species of octopi produce eruptions on the surface of the body. The octopus fishermen of Coroa Vermelha also identify this behavior and refer to it as frightening. This behavior avoids them to be found by their predators.

The octopi show another defense strategy that is the liberation of the ink of dark coloration kept in a gland that produces the smoke screen effect in the aquatic way (Caldwell 2005). The octopus fishermen refer to this substance as the "coffee" of the octopus ("That ink comes out of the una of the octopus. It has an 'una' where the coffee is made, doesn't it? There is the place where it prepares it (the coffee) to escape from the enemy, right? If you come back to catch it"). The ink composed of a suspension of melanin granules is stored in a gland of ink and liberated through the anus of the animal (Ruppert et al. 2005). According to Brusca and Brusca (2007), the ink forms outlines and silhouettes in the water that do not come undone quickly, thus confusing the predators.
The interviewed octopus fishermen, therefore, have an accurate knowledge regarding aspects of the behavior of the octopi that are, in many aspects, compatible with the specialized scientific literature, particularly in which concerns the strategies of defense of these animals such as mimicry and ink liberation.

\section{CONCLUSIONS}

The results obtained through this research showed that octopus fishermen of Coroa Vermelha have a broad knowledge about the octopi and the coral reefs environment. This knowledge is demonstrated through the ethnotaxonomy and identification of the trophic web elements, defense behaviors and strategies to cope with the natural resources.

Some of the knowledge is used in cultural strategies for the optimization of the production, since the capture depends upon knowledge about the dynamics of the tides, feeding and behavior of the octopi. It was found a considerable correspondence between the traditional and academic knowledge. In fact, this would be a reason to stimulate and encourage further research on ethnoecological aspects to a better understanding of the cultural and ecological dynamics of octopus fishing in coral reef areas.

\section{ACKNOWLEDGMENTS}

We thank the Community of Coroa Vermelha, especially the local octopus fishermen, for their care and reception. Professor Dr. Manoel Haimovici, Universidade Federal do Rio Grande (FURG), for the identification of the octopi, and Fundação de Amparo à Pesquisa do Estado da Bahia (FAPESB) for the concession of a master's degree scholarship to the first author. This article is part of the master's degree dissertation "Uma Abordagem Etnoecológica Abrangente da Pesca de Polvos na Comunidade de Coroa Vermelha" (Santa Cruz, Cabrália, Bahia - Brasil), defended at the Programa de Pós-graduação em Sistemas Aquáticos Tropicais da Universidade Estadual de Santa Cruz.

\section{RESUMO}

Os recifes de coral são ecossistemas muito diversos que realizam várias funções ecológicas e possuem um relevante papel socioeconômico. A pesca artesanal de polvo (Octopus spp.) é realizada para a sobrevivência de uma parte da popu- 
lação da comunidade de Coroa Vermelha, no Sul do Estado da Bahia. A intenção deste estudo foi avaliar o conhecimento dos pescadores de polvos de Coroa Vermelha, usando a proposta da etnoecologia abrangente de Marques. Os dados foram coletados entre julho de 2006 e abril de 2008 através da observação direta e entrevistas com pescadores encontrados oportunisticamente e com os especialistas "nativos". Vinte entrevistas semi-estruturadas foram realizadas seguindo um roteiro de perguntas pré-estabelecidas sobre a atividade de captura polvos, e os aspectos biológicos e ecológicos do recurso capturado. Os dados demonstraram que os pescadores têm conhecimento sobre alguns aspectos biológicos e ecológicos dos polvos. Duas técnicas de captura são utilizadas: pesca sobre o recife (polvejamento) e através de mergulho. Dois específicos do povos são reconhecidos: o polvo "normal" (Octopus insularis) e o polvo "de leste" (Octopus macropus (?)). Os entrevistados demonstraram conhecimento ecológico, por vezes, compatíveis com a literatura científica, principalmente no que diz respeito à ecologia trófica e comportamento dos polvos.

Palavras-chave: etnoecologia, pesca artesanal, recifes de corais, cefalópode.

\section{REFERENCES}

Belcari P, CUCCU D, GonzÁlez M, SRAiri A AND ViDORIS P. 2002. Distribuition and Abundance of Octopus vulgaris Cuvier, 1977 (Cephalopoda: Octopoda) in Mediterranean Sea. Sci Mar 66: 157-166.

BERLIN B. 1992. Ethnobiological Classification: principles of plants and animals in traditional societies, Princeton: Princeton University Press, 574 p.

Blackmore S. 2000. The power of memes. Sci Am 283: 52-61.

Boletzky SV, Fuentes M And Offner N. 2001. First Record of Spawning and Embryonic Development in Octopus macropus (Mollusca: Cephalopoda). J Mar Biol Ass UK 81: 703-704.

BoletzKy SV, Fuentès M AND OfFner N. 2002. Developmental Features of Octopus macropus Risso, 1826 (Mollusca: Cephalopoda). Vi Milieu 52: 209-215.

BRUSCA RC AND BRUSCA CJ. 2007. Invertebrados. $2^{\text {nd }}$ ed., São Paulo: Guanabara Koogan, 1098 p.

CALDWELL RL. 2005. An Observation of Inking Behavior Protecting Adult Octopus bocki from Predation by Green Turtle (Chelonia mydas) Hatchlings. Pac Sci 59: 69-72.

Cardoso F, Villegas P ANd Estrella C. 2004. Observaciones sobre la biología de Octopus mimus (Cephalopoda: Octopoda) en la costa peruana. Rev Peru Biol 11: $45-50$.
CEPHBASE. 2007. http://www.cephbase.utmb.edu/ Accessed on november 13.

Costa Neto EM. 2001. A cultura pesqueira do litoral norte da Bahia: etnoictiologia, desenvolvimento e sustentabilidade. Salvador/Maceió: EDUFBA/EDUFAL, 159 p.

DAWKINS R. 1979. O gene egoísta. Belo Horizonte: Itatiaia, $452 \mathrm{p}$.

Diegues AC. 2000. Etnoconservação: Novos rumos para a proteção da natureza nos trópicos. São Paulo: HUCITEC/ NUPAUB-USP, 290 p.

Diegues AC. 2001. Ecologia Humana e Planejamento Costeiro. $2^{\mathrm{a}}$ ed., São Paulo: NUPAUB-USP, 225 p.

FAO. 2002. The Living Marine Resources of the Western Central Atlantic 1 - Introduction, molluscs, crustaceans, hagfishes, sharks, batoid fishes and chimaeras. Roma: Food and Agriculture Organization of the United Nations, $600 \mathrm{p}$.

FORSYTHE JW AND HANLON RT. 1997. Foraging and associated behavior by Octopus cyanea Gray, 1849 on a coral atoll, French Polynesia. J Exp Mar Biol Ecol 209: 15-31.

Gurjão LM, Furtado-Neto MAA And SAntos RA. 2004. Análise de Conteúdos Estomacais de Quatro Golfinhos (Cetacea: Delphinidae) encalhados em praias no litoral do Estado do Ceará, Brasil. Rev Bios 10: 39-45.

HANLON R. 2007. Cephalopod dynamic camouflage. Curr Biol 17: 400-404.

JAMBEIRO AF. 2002. Biologia Quantitativa da população de Octopus vulgaris Cuvier, 1797 no ecossistema recifal de Guarapuá, Cairu - Bahia. Universidade Federal da Bahia, Departamento de Ciências Biológicas, 110 p.

JOHANNES RE. 1981. Working with Fishermen to Improve Coastal Tropical Fisheries and Resource Management. Bull Mar Sci 31: 673-680.

LEITE TS. 2007. Taxonomia, Distribuição, Ecologia alimentar e Opções de Manejo de uma Nova Espécie de Polvo (Octopus insularis: Cephalopoda) no Arquipélago de Fernando de Noronha, Brasil. Universidade do Rio Grande, $94 \mathrm{p}$.

Leite TS, Haimovici M And Lins JE. 2008a. A Pesca de Polvos no Arquipélago de Fernando de Noronha, Brasil. Bol Inst Pesca São Paulo 34: 271-280.

Leite TS, Haimovici M AND Lins JE. 2008b. Uma Proposta de Manejo Para a Pesca de Polvo (Mollusca: Cephalopoda) na Área de Proteção Ambiental do Arquipélago de Fernando de Noronha, Brasil. Arq Cie Mar 41: 81-89.

Leite TS, Haimovici M, Molina W AND Warnke K. 2008c. Morphological and Genetic Description of Octopus insularis n. sp. (Mollusca: Octopodidae), a Cryptic Species Into the Octopus vulgaris Complex From the Tropical South-Western Atlantic. Moll Stud 74: 63-74. 
Leite TS AND Mather J. 2008. A new approach to octopuses' body pattern analysis: a framework for taxonomy and behavioral studies. Am Malacol Bull 24: 31-41.

Marques JGW. 1991. Aspectos Ecológicos na Etnoictiologia dos pescadores do Complexo Estuarino-Lagunar Mundaú-Manguaba, Alagoas. Universidade Estadual de Campinas, $292 \mathrm{p}$.

Marques JGW. 1995. Pescando pescadores: Etnoecologia Abrangente no Baixo São Francisco. São Paulo: NUPAUB-USP, 304 p.

Marques JGW. 2001. Pescando pescadores: Ciência e Etnociência em uma Perspectiva Ecológica. São Paulo: NUPAUB-USP, $258 \mathrm{p}$.

Materazzi L. 2006. Cultivo de Polvo Comum Octopus vulgaris (Cuvier 1797). Universidade de Taubaté, 22 p.

Meisel DV, Byrne RA, Kuba M, Mather J, PloberGER W AND RESCHENHOFER E. 2006. Contrasting activity patterns of two related octopus species, Octopus macropus and Octopus vulgaris. J Comp Psychol 120: 191-197.

Montenegro SCS. 2002. A Conexão Homem/Camarão (Macrobrachium carcinus e M. acanthurus) no Baixo Sul Alagoano: uma abordagem etnoecológica. Universidade Federal de São Carlos, 210 p.

Mourão JS. 2000. Classificação e Ecologia de Peixes Estuarinos por Pescadores do Estuário do Rio Mamanguape PB. Universidade Federal de São Carlos, 132 p.

Mourão JS And Montenegro SCS. 2006. Pescadores e Peixes: O conhecimento local e o uso da taxonomia folk baseado no modelo berliniano v. 2. Recife: NUPEEA, $70 \mathrm{p}$.

Mourão JS ANd Nordi N. 2006. Pescadores, Peixes, Espaço e Tempo: uma abordagem etnoecológica. InterCie 31: 358-363.

NishidA AK. 2000. Catadores de Molusco do Litoral Paraibano: Estratégias de subsistência e formas de percepção da natureza. Universidade Federal de São Carlos, 143 p.

PosEY D. 1987. Etnobiologia: teoria e prática. In: RIBEIRO D (Eds), Suma Etnológica Brasileira v. 1, Petrópolis: Vozes, p. 15-25.

Quetglas A, Alemany F, Carbonell A, Merella P AND SÂNCHEZ P. 1998. Biology and Fishery of Octopus vulgaris Cuvier, 1797, caught by trawlers in Mallorca (Balearic Sea, Western Mediterranean). J Fish Res 36: 237-249.

Richardson RJ, Peres JAS, Wanderley JCV, CorReIA LM AND PERES MHM. 2007. Pesquisa social. Métodos e técnicas. $3^{\mathrm{a}}$ ed., São Paulo: Atlas.
RUPPERT EE, FOX RS AND BARNES RD. 2005. Zoologia dos Invertebrados, $7^{\mathrm{a}}$ ed., São Paulo: Roca, 1145 p.

SANTAMARIÑA XAF. 1998. Arredor do Polbo: do mar à montaña. In: LouRIDo FC (Ed), Proceedings... Actas do Simposio Internacional Antropoloxía Mariñeira: in memoriam Xosé Filgueira Valverde. Santiago de Compostela: Consello da Cultura Galega, $361 \mathrm{p}$.

SEAP - SECRETARia ESPECIAL DE Aquicultura E PESCA. 2004. Normative Instruction N. 3. Dispõe sobre operacionalização do Registro Geral da Pesca.

SEMARH - SECRETARIA DE MEIO AMBIENTE E RECURSOS HÍdRICOS DO ESTADO DA BAHIA. 2007.

http://www.semarh.ba.gov.br/

Template.asp?nivel $=0006001200060002$

\&identidade $=278$ Accessed on january 20.

SEMMENS JM ET AL. 2007. Approaches to resolving cephalopod movement and migration patterns. Rev Fish Biol Fisheries 17: 401-423.

Silvano RAM. 2001. Etnoecologia e História Natural de Peixes no Atlântico (Ilha de Búzios, Brasil e Pacífico (Moreton Bay, Austrália). Universidade Estadual de Campinas, $290 \mathrm{p}$.

SoUto FJB. 2004. A ciência que veio da lama: Uma abordagem Etnoecológica Abrangente das Relações Ser Humano/Manguezal na Comunidade Pesqueira de Acupe, Santo Amaro, Bahia. Tese. São Carlos' Federal University, 322 p. (Unpublished).

TomÁs ARG. 2003. Dinâmica de População e Avaliação do Estoque do Polvo Comum, Octopus cf. vulgaris Cuvier, 1797 (Mollusca, Cephalopoda, Octopodidae) do SudesteSul do Brasil. Universidade Estadual Paulista Júlio de Mesquita Filho, 460 p.

Tsangridis A, SÁnchez P And IoAnnidou D. 2002. Explotaition patterns of Octopus vulgaris in two Mediterranean areas. Sci Mar 66: 59-68.

VERGARA-FILho WL. 2001. A Educação Ambiental, como instrumento de cidadania das populações pesqueiras e conservação dos recursos do manguezal. Maragogipe Brazil. Proceedings... III Encontro Nacional de educação ambiental em áreas de manguezais, p. 35-42.

WARnKe K, SÖller R, Blohm D And SAint-PAul U. 2004. A New Look at Geographic and Phylogenetic Relationships Within the Species Group Surrounding Octopus vulgaris (Mollusca, Cephalopoda): indications of very wide distribution from mitochondrial DNA sequences. J Zool Syst Evol Research 42: 306-312. 